\title{
PEMBELAJARAN BERBASIS MASALAH (PROBLEM BASED LEARNING) SECARA ONLINE SELAMA PANDEMI COVID-19
}

\section{Yunita Pare Rombe ${ }^{*}$, Murtihapsari2*, Fitria Alberta ${ }^{3}$, Radite Yogaswara ${ }^{4}$, Putri Sarera Surbakti ${ }^{5}$}

\section{A R T I C L E I N F O}

\section{Article history:}

Received August 11, 2021

Revised August 15, 2021

Accepted October 01, 2021

Available online October 25, 2021

Kata Kunci:

Miskonsepsi, Kesetimbangan Kimia, Strategi PDEODE

Keywords:

Media Padlet, Phet Simulation

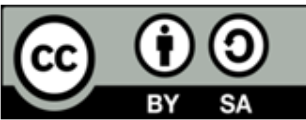

This is an open access article under the CC BY-SA license.

Copyright $(2021$ by Author. Published by Universitas Pendidikan Ganesha.

\begin{abstract}
A B S T R A K
Pandemi COVID-19 menyebabkan semua elemen penggerak pendidikan meliputi guru, peserta didik dan pemerintah mengalami kesulitan untuk memaksimalkan proses pemebelajaran di kelas. Penelitian ini bertujuan untuk menganalisis pembelajaran berbasis masalah (Problem Based Learning) secara online selama pandemic Covid-19. Jenis penelitian ini merupakan penelitian literature. Penelitian ini dikaji dari berbagai artikel dari penelitian sebelumnya yang telah terpublikasi nasional pada jurnal ilmiah terakreditasi. Instrumen pada ulasan ini berupa 26 artikel- artikel yang memiliki tema yang relevan kemudian dikumpulkan, lalu dipilah sesuai kriteria yang ditetapkan. Selanjutnya teknik pengumpulan artikel-artikel pada ulasan ini dikaji berdasarkan kriteria: (1) penelitian eksperimen atau pre eksperimen, penelitian tindakan kelas, penelitian kuantitatif, (2) subjek penelitian melibatkan peserta didik MIPA SMA/MA/SMK. Teknik analisis kajian terhadap data dengan cara mendeskripsikan secara singkat hasil penelitian dari artikel-artikel tersebut, selanjutnya ditarik simpulan. Hasil penelitian menunjukkan model pembelajaran Problem Based Learning menggunakan dapat mendukung proses berlangsungnya pembelajaran dengan baik dan dapat mempermudah peserta didik serta guru dalam berinteraksi walaupun secara online. Maka, secara keseluruhan model pembelajaran problem based learning (PBL) memberikan pengaruh positif terhadap kegiatan pembelajaran. implikasi penelitian ini diharapkan dapat membantu siswa dalam memecahkan permasalahan selama pembelajaran online.
\end{abstract}

\section{A B S T R A C T}

The COVID-19 pandemic has made it difficult for all elements of education, including teachers, students and the government, to maximize the learning process in the classroom. This study aims to analyze online problem-based learning during the Covid-19 pandemic. This type of research is a literature research. This research is reviewed from various articles from previous research that have been published nationally in accredited scientific journals. The instrument in this review is in the form of 26 articles that have relevant themes which are then collected, then sorted according to the established criteria. Furthermore, the technique of collecting the articles in this review was reviewed based on the following criteria: (1) experimental or pre-experimental research, classroom action research, quantitative research, (2) research subjects involving high school/MA/vocational MIPA students. The analysis technique of the study of the data was by briefly describing the results of the research from these articles, then conclusions were drawn. The results of the study show that the Problem Based Learning learning model can support the learning process well and can make it easier for students and teachers to interact even online. So, overall the problem based learning (PBL) learning model has a positive influence on learning activities. The implications of this research are expected to help students in solving problems during online learning. 


\section{PENDAHULUAN}

Negara Indonesia mempunyai harapan yang sangat besar dalam dunia Pendidikan. Pendidikan sangat penting untuk dikembangkan dalam hidup manusia guna membangun masyarakat dan negara. Segala upaya terus dilakukan demi memperbaiki sistem pendidikan agar sesuai dengan perkembangan zaman yang mampu berdaya saing (I. Y. Rahmawati \& Yulianti, 2020; Safithri et al., 2021). Akibat Kondisi Covid-19, beberapa instansi menerapkan Work from Home (WFH) atau bekerja dari rumah, termasuk juga lembaga atau instansi pendidikan (Handarini \& Wulandari, 2020; Purwanto et al., 2020; Sa et al., 2021). Pemerintah memberi kebijakan bagi setiap sekolah untuk melakukan pembelajaran secara daring, yakni dengan menggunakan gadget (laptop atau HP) untuk mengakses Website atau Link pembelajaran daring seperti Google Form, Microsoft 365, Google Classroom, dll (Basar, 2021; Wijayanti \& Fauziah, 2020). Kebijakan pelaksanaan daring bagi siswa telah ditetapkan oleh pemerintah Indonesia melalui Surat Edaran Kementerian Pendidikan dan Kebudayaan Indonesia Nomor 4 Tahun 2020 tentang Pelaksanaan Pendidikan Dalam Masa Darurat Covid-19 dan diperkuat dengan Surat Edaran Sesjen nomor 15 tahun 2020 tentang Pedoman Pelaksanaan BDR selama darurat Covid-19 yang menyatakan bahwa tujuan Belajar Dari Rumah (BDR) adalah untuk memenuhi standard pendidikan melalui pemanfaatan teknologi informasi dengan menggunakan perangkat komputer atau gadget yang saling terhubung antara siswa dan guru(Marroquín et al., 2020; Nurkholis, 2020).

Namun kenyataannya pembelajaran daring masih memiliki banyak kendala, peserta didik juga mengalami kesulitan dari segi interaksi dimana tidak adanya bimbingan dari seorang guru sehingga mata pelajaran yang dipelajari mengalami kendala yang berdampak nyata pada minat dan prestasi belajar (Agustin, 2020; Syafari \& Montessori, 2020). Proses belajar online dapat berdampak pada minat dan prestasi belajar dari peserta didik (Ota et al., 2021; Yunitasari \& Hanifah, 2020). Kurangnya interaksi dan minat belajar peserta didik disebabkan karena model pembelajaran diberikan oleh guru belum dapat memancing peserta didik untuk aktif dalam proses pembelajaran yang berujung siswa tidak termotivasi untuk ikut aktif dalam proses pembelajaran. Sehingga guru perlu menggunakan model pembelajaran yang cocok untuk meningkatkan aktivitas belajar peserta didik dibutuhkan suatu pembelajaran inovatif dan efektif untuk diterapkan pada pembelajaran online. Para guru mengalami kesulitan dalam pengembangan kurikulum yang sesuai dengan pembelajaran daring, pengelolaan pembelajaran, penanaman karakter peserta didik peserta didik sulit dilaksanakan karena keterbatasan interaksi dengan peserta didik, maupun keterbatasan upaya pemberdayaan peserta didik (Abidah et al., 2020; Ferazona \& Suryanti, 2020; Patabang \& Murniarti, 2021). Jika permasalahan tersebut dibiarkan maka akan memberikan dampak buruk bagi kualitas pendidikan.

Solusi yang dilakukan dalam pembelajaran secara online diantaranya peningkatan kualitas guru, pembagian pulsa data kepada peserta didik, perubahan model pembelajaran (pembelajaran daring), penyempurnaan sistem penilaian, penggunaan model, metode yang sesuai dan menarik. Salah satu alternatif model pembelajaran yang efektif dapat digunakan pembelajaran berbasis masalah (Problem Based Learning). Kegiatan belajar mengajar berdasarkan pada masalah dan menyajikan masalah dengan kondisi yang autentik dan bermakna sehingga dapat memotivasi peserta didik melaksanakan investigasi masalah (Kiswanto et al., 2016). Potret kegiatan belajar mengajar secara daring di masa pandemi ini memiliki perkembangan sehingga peserta didik tidak lagi kesulitan menggunakan bantuan alat elektronik dalam mengembangkan kreativitasnya dari awal hingga saat ini (Harta, 2019). Selain itu, ketepatan dalam penggunaan model dan metode pembelajaran terdapat kelebihan yang dimiliki peserta didik dalam mengembangkan pembelajaran menuntut adanya kreativitas, karena hal ini yang dapat mendukung perkembangan individu tersebut. Kreativitas diperoleh dari hasil interaksi antara individu dan lingkungannya sehingga dapat meningkatkan kualitas hidup. Peserta didik yang memiliki kreativitas dalam dirinya diharapkan mampu melakukan inovasi untuk menghasilkan sesuatu yang baru dan mempertahankan prestasi belajar pada saat pandemi (Kuswariningsih, 2016; Nurfitriyani, 2015).

Temuan terkait pembelajaran berbasis masalah sudah banyak dilakuka, problem based learning dapat dikatakan sebagai suatu proses pembelajaran yang menantang siswa untuk belajar secara berkelompok dalam mencari solusi dari permasalahan dunia nyata kemudian dituntut untuk memecahkan masalah tersebut (Kristiana \& Radia, 2021; Saputro \& Rayahu, 2020). Penggunaan model Problem Based Learning bertujuan untuk meningkatkan kreativitas peserta didik dapat berpikir kritis dan kreatif dalam proses pembelajaran (Al-Fikry et al., 2018; Cahyo et al., 2018). Penelitian sebelumnya menerapkan model pembelajaran problem based learning pada pembelajaran offline, sedangkan pada penelitian ini penerapan model problem based learning pada pembelajaran online. Maka tujuan penelitian ini untuk menganalisis penggunaan model pembelajaran online dari peserta didik agar dapat meningkatkan kreativitas dalam dirinya melalui pembelajaran online. Adanya penerapan model pembelajaran problem based learning dapat membantu guru dan siswa selama pembelajaran online. 


\section{METODE}

Jenis penelitian ini merupakan penelitian literature. Penelitian ini dikaji dari berbagai artikel dari penelitian sebelumnya yang telah terpublikasi nasional pada jurnal ilmiah terakreditasi. Target dalam ulasan ini dari beberapa literatur dikumpulkan yang terkait tema relevan tentang kajian proses pembelajaran online dengan menggunakan model Problem Based Learning (PBL). Bagan alir penelitian disajikan pada Gambar 1. Instrumen pada ulasan ini berupa artikel- artikel yang memiliki tema yang relevan kemudian dikumpulkan, lalu dipilah sesuai kriteria yang ditetapkan. Selanjutnya teknik pengumpulan artikel-artikel pada ulasan ini dikaji berdasarkan kriteria: (1) penelitian eksperimen atau pre eksperimen, penelitian tindakan kelas, penelitian kuantitatif, (2) subjek penelitian melibatkan peserta didik MIPA SMA/MA/SMK Berdasarkan kriteria data yang diperlukan dalam ulasan ini, maka terdapat 26 (dua puluh enam) artikel yang sesuai dengan tema. Kemudian dilakukan analisis kajian terhadap data dengan cara mendeskripsikan secara singkat hasil penelitian dari artikel-artikel tersebut, selanjutnya ditarik simpulan. Jadi metode pada kajian ini lebih ditekankan pada studi terpenting dan terkini dari beberapa literatur yang membahas model pembelajaran online melalui Problem Based Learning (PBL).

\section{HASIL DAN PEMBAHASAN}

Hasil

Proses pembelajaran di masa pandemi covid 19 dilaksanakan secara online. Pembelajaran online selama pandemi covid-19 dilakukan dengan menggunakan model pembelajaran problem based learning dengan tujuan untuk meningkatkan hasil belajar selama masa pandemi. Berdasarkan studi literatur yang dilakukan dapat dibagi dalam beberapa kajian yaitu a) Model problem based learning, b) model pembelajaran berbasis PBL menggunakan metode eksperimen, c) Pengaruh pembelajaran online terhadap hasil belajar.

Pertama, model pembelajaran berbasis masalah sangat berpengaruh tehadap hasil belajar peserta didik seperti peserta didik mampu berpikir kritis lebih aktif, kreatif dan mampu memecahkan masalah. Kelebihan pembelajaran berbasis masalah diantaranya 1) peserta didik dituntut agar dapat memecahkan permasalahan pada kondisi yang ril. 2) peserta didik dapat melihat kemampuan yang dimiliki. 3) peserta didik terbiasa dengan adaptasi teknologi sehingga model pembelajaran berbasis masalah sangat tepat digunakan dalam proses pembelajaran (Lidinillah, 2013). Temuan penelitian sebelumnya menyatakan bahwa pembelajaran berbasis masalah menggunakan media online memberi dampak positif pada hasil belajar peserta didik seperti keampuan untuk berpikir kritis dan kreatif. Hasil penelitian menunjukkan nilai thitung $=2.57>$ tabel $=2.4$ menandakan bahwa Ho ditolak pada $\alpha=0.05$ (Zakia et al., 2019). PBL melalui pembelajaran online memberi hasil yang baik terhadap prestasi belajar peserta didik. Berdasarkan hasil penelitian menunjukkan rerata persentase sebesar $83 \%$ untuk kelas eksperimen, sedangkan kelas kontrol persentase rerata sebesar $63 \%$. Perolehan nilai sig $0,000<0,005$, sehingga dapat ditarik kesimpulan bahwa pembelajaran PBL secara online dapat lebih efektif dan meningkatkan kreativitas belajar peserta didik (Aminah, 2021).

Kedua, model PBL memberi pengaruh terhadap hasil belajar seperti aktivitas dan kompetensi peserta didik (Saputri et al., 2021). Berdasarkan hasil penelitian menunjukkan bahwa PBL memberi pengaruh terhadap hasil belajar dengan nilai kelas kontrol 73,88 dan kelas eksperimen 79,58. Hasil nilai sig 0,000. Jadi disimpulkan bahwa pembelajaran menggunakan PBL secara online pada kelas ekperimen, peserta didik lebih aktif dan hasil belajar yang signifikan. Temuan penelitian sebelumnya menyatakan model pembelajaran berbasis masalah dengan tujuan untuk mengetahui pengaruh terhadap hasil belajar peserta didik. Berdasarkan hasil penelitian menunjukkan hasil yang sangat baik dilihat dari tanggapan positif dari peserta didik dengan persentase sebesar $91,7 \%$ sedangkan tanggapan negatif sebesar 8,3\%, sehingga dapat disimpulkan bahwa penerapan model pembelajaran berbasis masalah dapat meningkatkan prestasi belajar peserta didik (Lidyawati et al., 2017). Temuan lain juga menyatakan penerapan model pembelajaran berbasis masalah dapat meningkatkan kemampuan dan sikap yang baik dari peserta didik dengan nilai rata-rata sebesar $86,29 \%$, dan 90,63\% memiliki sikap yang baik (Pratiwi et al., 2014).

Ketiga, sistem pendidikan sekarang ini masih tergolong rendah dalam mendukung kecakapan peserta didik untuk berpikir kreatif (Rosa \& Pujiati, 2017). Proses pembelajaran sangat jarang melatih peserta didik memliki kreativitas yang berdampak pada terbatasnya wawasan dan keterampilan dari peserta didik. Oleh karena itu, perlu ada motode pembalajaran yang berbasis masalah agar peserta didik dapat memecahkan masalah yang lebih luas dan memiliki kreativitas yang tinggi. Berdasarkan hasil penelitian yang dilakukan didapatkan skor kemampuan berpikir kreatif model pembelajaran berbasis masalah sebesar 26,87, sedangkan skor kemampuan berpikir menggunakan model ekspositori sebesar 
20,70, sehingga dapat disimpulkan bahwa kemampuan berpikir kreatif dapat meningkat dengan menggunakan model berbasis malasah. Temuan ini menyatakan pembelajaran berbasis masalah berdasarkan hasil penelitian yang telah dilakukan didapatkan hasil masing-masing dengan persentase sebesar kelas kontrol 77,01\% sedangkan kelas eksperimen sebesar 85,74\%, sehingga dapat disimpulkan bahwa pembelajaran berbasis masalah dapat meningkatkan kreativitas, peserta didik aktif di dalam kelas, mampu melakukan diskusi dengan baik dan dapat menambah wawasan (Abdurrozak \& Jayadinata, 2016).

Keempat, temuan lain menyatakan penerapan model pembelajaran berbasis masalah dapat meningkatkan kemampuan berpikir kritis, mengembangkan potensi, peserta didik lebih termotivasi dalam belajar sehinggga dapat memperoleh hasil yang maksimal dalam proses pembelajaran. PBL yang berdampak pada prestasi belajar (Al-Fikry et al., 2018). Hasil penelitian ini menunjukkan adanya peningkatan signifikan hasil belajar peserta didik dari pretest $(44,32 \%)$, posttest $(92,32 \%)$ dan $N$-Gain (86,59\%). Selanjutnya, adanya pengaruh model pembelajaran berbasis masalah terhadap sikap kemampuan dalam berpikir kritis (Astika et al., 2013). Berdasarkan hasil didapatkan nilai sebesar $\mathrm{F}=19,630$; $\mathrm{p}<0,05$ yang menunjukkan bahwa adanya pengaruh sikap dan kemampuan berpikir kritis antara peserta didik yang dalam proses belajar menggunakan model pembelajaran berbasis masalah dan peserta didk yang belajar dengan model pembelajaran ekspositori. Berpikir kritis merupakan suatu proses yang membutuhkan keterampilan dalam menyelesaikan suatu masalah seperti dalam hal mengambil keputusan dan analisa masalah sehingga peningkatan kualitas pendidikan dapat tercapai.

Kelima, model pembelajaran berbasis PBL menggunakan metode eksperimen dilakukan dengan tujuan agar aktivitas dan prestasi hasil belajar mengalami peningkatan. Berdasarkan hasil penelitian yang dilakukan maka diperoleh hasil belajar kognitif thitung>ttabel $(4,88>2,00)$ dan aktivitas peserta didik dengan hasil penelitian diperoleh hasil $t_{\text {hitung }}>t_{\text {tabel }}(5,44>2,00)$. Jadi dapat disimpulkan bahwa PBL menggunakan metode eksperimen dapat meningkatkan prestasi belajar, lebih aktif, mampu berpikir kritis dan memecahkan permasalahan (Nafis, Khusnul, 2020). Selain itu, model pembelajaran PBL dengan tujuan untuk membuktikan dampak dari PBL terhadap kemampuan berpikir kritis peserta didik (Farisi et al., 2017). Hasil Uji hipotesis dengan nilai $t_{\text {hitung }}>t_{\text {tabel }}(6,72>1,68)$, sehingga ditarik simpulkan $t_{\text {hitung }}>t_{\text {tabel, }}$ $\mathrm{H}_{\mathrm{a}}$ diterima dan $\mathrm{H}_{0}$ ditolak. Proses belajar yang diketahui berhasil adalah ketika peserta didik telah mencapai kompetensi yang diinginkan. Guru perlu memilih model yang tepat dalam proses pembelajaran. berbasis masalah karena dapat meningkatkan dan mengembangkan sikap ilmiah dalam hasil belajar(Nisa, 2017). Penelitian yang telah dilakukan di MIA 2 pada kelas X dengan teknik pengumpulan data melalui pretest, posttest, survei. Berdasarkan hasil penelitian diperoleh nilai analisis $t_{\text {hitung }}=4,46>t_{\text {tabel }}=1,99$. Jadi ditarik kesimpulan bahwa PBL pada materi ikatan kimia berdampak positif pada sikap ilmiah dan hasil belajar kognitif peserta didik.

Keenam, pembelajaran menggunakan metode eksperimen dilakukan untuk membuktikan suatu teori yang dipelajari. Penerapan metode ekperimen diterapkan dengan tujuan agar peserta didik memiliki kreativitas yang tinggi, mampu berpikir kritis yang berujung pada prestasi hasil belajar yang baik. Adanya dampak dari penggunaan metode eksperimen berbasis masalah terhadap prestasi belajar peserta didik pada kelas XI IPA SMAN 1 Depok (Wulandari, A., dan Rohaeti, 2017). Hasil penelitian ini berdasarkan analisis uji-t kelas eksperimen yang memperoleh hasil sig<0,05, menunjukkan bahwa adanya pengaruh setelah menerapkan metode eksperimen berbasis masalah yaitu peningkatan sikap ilmiah pada kelas eksperimen dibandingkan kelas kontrol. Menerapkan model pembelajaran berbasis masalah dengan metode eksperimen pada materi kimia (Wulandari, A., dan Rohaeti, 2017). Hasil analisa uji-t kelas eksperimen memeperoleh nilai sig<0,05 $(0,741)$ dan kelas kontrol memperoleh nilai sig $>0,05$, sehingga dapat disimpulkan bahwa sikap ilmiah peserta didik kelas eksperimen meningkat walaupun tidak ada perbedaan yang signifikan pada sikap peserta didik terhadap pembelajaran di kelas kontrol. Permasalahan dalam proses pembelajaran dapat membuat peserta didik lebih mendalami ide dan gagasan suatu pelajaran, sehingga adanya keingintahuan karena terdapat masalah yang berujung pada peningkatan sikap dan prestasi belajar peserta didik.

Ketujuh, Selain itu, model PBL menggunakan metode eksperimen untuk mengetahui adanya pemahaman konsep yang dilihat dari cara berpikir kritis peserta didik (Suriana et al., 2016). Penelitian ini dilakukan di MAN Rukoh Banda Aceh pada kelas XI dengan jumlah peserta didik kelas kontrol 25 (dua puluh lima) orang dan kelas eksperimen 24 (dua puluh empat) orang. Hasil penelitian menunjukkan persentase kelas eksperimen dan kelas kontrol masing-masing sebesar $71 \%$ dan $32 \%$, terlihat adanya peningkatan yang signifikan disebabkan karena adanya pengaruh dengan menerapkan PBL berbaris eksperimen dapat meningkatkan pemahaman konsep dan cara berpikir. Selanjutnya dampak model pembelajaran PBL dengan metode eksperimen ditinjau dari aspek kognitif, afektif dan psikomotorik (Assriyanto et al., 2014). Aspek kognitif dengan nilai $F_{\text {obs }}>F_{\text {tabel }}(9,111>4,00)$ menandakan $\mathrm{H}_{0 A}$ ditolak. Aspek afektif dengan nilai sebesar $\mathrm{F}_{\mathrm{obs}}>\mathrm{F}_{\text {tabel }}(60,650>4,00)$ yang berarti bahwa $\mathrm{H}_{0 \mathrm{~A}}$ ditolak. Aspek psikomotorik didapatkan hasil $\mathrm{F}_{\mathrm{obs}}<\mathrm{F}_{\text {tabel }}(0,172<4,00) \mathrm{H}_{0 \mathrm{~A}}$ diterima. Berdasarkan ketiga aspek tersebut 
disimpulkan bahwa PBL memberi dampak signifikan terhadap prestasi belajar kognitif dan afektif tetapi aspek prikomotorik tidak terdapat dampak yang signifikan setelah menggunakan metode PBL dengan metode eksperimen.

Kedelapan, pembelajaran berbasis masalah dilakukan agar peserta didik lebih aktif, dan peserta didik didorong untuk dapat memecahkan malasah dalam pembelajaran yang disajikan (Aziz et al., 2015). Peneltian di SMAN 1 Gunungsari pada Kelas X untuk membuktikan adanya dampak PBL. Penelitian ini bertujuan untuk mengetahui pengaruh model pembelajaran berbasis masalah dengan metode eksperimen. Hasil penelitian menunjukkan nilai analisis uji-t, dapat dilihat thitung $=9,25>t_{\text {tabel }}=1,99$ dan nilai signifikansi $5 \%$ yang berarti bahwa $\mathrm{H}_{a}$ diterima dan $\mathrm{H}_{0}$ ditolak. Jadi dari hasil penelitian dapat disimpulkan bahwa materi tidak hanya dengan teori menghafal tetapi materi yang dipelajari perlu dikaitkan dengan keadaan nyata sehingga peserta didik dapat memecahkan masalah yang ditemukan dan peserta didik lebih aktif. Adanya dampak positif dari model pembelajaran Problem Based Learning terhadap kompetensi dan hasil belajar peserta didik (E. Rahmawati, 2020). Berdasarkan hasil analisis uji-t diperoleh $t_{\text {hitung }}>t_{\text {tabel }}(15,59>1,671)$, menandakan $\mathrm{H}_{a}$ diterima dan $\mathrm{H}_{0}$ ditolak. Jadi dapat disimpulkan bahwa Problem Based Learning memberi dampak yang baik terhadap hasil belajar peserta didik.

Kesembilan, pembelajaran berbasis online mendapat respon yang baik dari masyarakat karena informasi dapat tersampaikan dengan cepat. Pembelajaran menggunakan model Problem Based Learning dan media pembelajaran berbasis online dapat meningkatkan hasil belajar peserta didik. Hasil penelitian yang telah dilakukan di SMKN 2 Tondano pada kelas XI membuktikan dengan nilai thitung $=15,91>t_{\text {table }}=2,045$ dengan nilai sig $>0,05$ yang berarti $H_{a}$ diterima. Begitupun dengan pembelajaran berbasis online dapat meningkatkan hasil prestasi belajar peserta didik. Hasil penelitian dengan nilai thitung $=18,14>t_{\text {tabel }}=2.045$, nilai sig $>0,05$ yang berarti $H_{a}$ diterima (Larumpa, Natalia, $S$ et al., 2020). Ferazona \& Suryanti (2020), melakukan penelitian tentang pengaruh pembelajaran online terhadap hasil belajar kognitif dari seorang pelajar. Hasil penelitian menunjukkan nilai yang sangat baik dan baik dengan persentase masing-masing sebesar 53,33\% dan 46,6\%, sehingga dapat disimpulkan bahwa pembelajaran online tidak menjadi penghalang dalam mendapatkan pengetahuan, keterampilan dan prestasi belajar yang baik. Oleh sebab itu, pembelajaran daring perlu dioptimalkan dalam pelaksanaan proses pembelajaran.

\section{Pembahasan}

Hasil yang ditemukan dalam menganalisis pembelajaran online mengalami kenaikan persepsi peserta didik dengan bantuan media google meet, google classroom, zoom meeting, dan lain-lain. Pembelajaran online juga terdapat banyak dampak positif dan negatif. Dampak positif pembelajaran berbasis online diantaranya peserta didik mempunyai kesempatan untuk mengenal media elektronik dengan baik selama masa pandemi, dan banyak hal-hal baru yang didapatkan dengan belajar online seperti belajar mandiri mengunakan aplikasi YouTube, Google dan Zoom. Selain itu, peserta didik dapat berkreasi dengan cara mengembangkan kreativitas dan kemampuan koognitif. Dampak negatifnya adalah peserta didik kurang fokus dalam mengikuti pembelajaran karena adanya berbagai faktor seperti tidak adanya pengawsan dari orang tua, penggunaan media sosial ke hal negatif, menurunnya kemampuan dalam belajar dan peserta didik memiliki kecenderungan lamban dalam menerima suatu materi. Hal ini menunjukkan bahwa model pembelajaran berbasis masalah yang dirancang dan diperkirakan mampu mengembangkan dan meningkatkan keterampilan peserta didik di masa pandemi dengan menggunakan pembelajaran eksperimen dan melakukan percobaan mampu meningkatkan daya ingat dan semangat belajar peserta didik.

Secara keseluruhan model pembelajaran problem based learning (PBL) memberikan pengaruh positif terhadap kegiatan pembelajara khususnya dalam aspek kognitif yaitu berpikir kritis. Kriteria model pembelajaran problem based learning (PBL) yang mengusung konsep penemuan melalui penyajian masalah yang kemudian dipecahkan sendiri oleh peserta didik dirasa sesuai untuk diteapkan pada pembelajaran (Hendriana, 2018; HS et al., 2019). Model problem based learning merupakan sebuah model pembelajaran yang menyediakan pengalaman autentik yang mendorong siswa untuk belajar aktif, mengkonstruksi pengetahuan, dan mengintegrasikan konteks belajar di sekolah dan belajar di kehidupan nyata secara alamiah(Al-Fikry et al., 2018; Safithri et al., 2021). Siswa yang menggunakan model problem based learning yang memiliki sikap ilmiah tinggi memiliki hasil belajar yang lebih baik dari pada siswa yang memiliki sikap ilmiah rendah. Model pembelajaran berbasis masalah memberikan kesempatan kepada semua siswa untuk aktif dalam proses pembelajaran, terlebih lagi untuk menyelesaikan permasalahan yang disedikan dalam proses pembeajaran dengan cara melakukan eksperimen dan diskusi sehingga siswa dapat membuktikan sendiri dengan melakukan sendiri proses percobaan untuk membuktikan serta melakukan diskusi untuk menyelesaikan permasalahan yang telah disediakan. 
Keberhasilan model pembelajaran problem based learning (PBL) dalam meningkatkan kemampuan berpikir kritis menunjukkan angka peningkatan yang berbeda-beda pula. Beragamnya angka peningkatan antara satu penelitian dengan penelitian lainnya tentu terjadi akan adanya faktor yang mempengaruhi. Faktor ini terbagi menjadi faktor intrinsik dan faktor ekstrinsik. Faktor intrinsik meliputi tingkat keinginan peserta didik untuk berhasil dalam pembelajaran, tingkat dorongan belajar, dan keinginan mewujudkan cita-cita. Sedangkan faktor ekstrinsik meliputi adanya reward, tingkat kondusif dalam kegiatan belajar, serta adanya kegiatan yang menarik dalam belajar (Febrina \& Airlanda, 2020; Utama \& Kristin, 2020). Secara keseluruhan, keunggulan penelitian ini yaitu memberikan gambaran mengenai keberhasilan model pembelajaran problem based learning (PBL) yang dapat diterapkan dalam proses pembelajaran online.

\section{SIMPULAN DAN SARAN}

Penggunaan media pembelajaran yang cocok selama pandemi dapat membantu meningkatkan kreativitas dan perkembangan potensi berpikir kritis pada peserta didik melalui pembelajaran secara online. Selain itu pula dapat lebih mengandalkan diri dalam memecahkan masalah yang diberikan oleh guru. Berdasarkan hasil yang diperoleh model pembelajaran Problem Based Learning menggunakan metode eksperimen dapat mendukung proses berlangsungnya pembelajaran dengan baik dan dapat mempermudah peserta didik serta guru dalam berinteraksi walaupun secara online. Selaian itu, model pembelajaran Problem Based Learning menggunakan metode eksperimen mampu meningkatkan hasil belajar peserta didik seperti peserta didik mampu berpikir kritis, lebih aktif, kreatif dan mampu memecahkan masalah. Studi literatur ini perlu dikaji lebih lanjut dengan membandingkan artikel-artikel yang diterbitkan dari jurnal terindeks scopus agar menambah khasanah keilmuan mengenai penggunaan model pembelajaran Problem Based Learning.

\section{DAFTAR RUJUKAN}

Abdurrozak, R., \& Jayadinata, A. K. (2016). Pengaruh Model Problem Based Learning Terhadap Kemampuan Berpikir Kreatif Siswa. Jurnal Pena Ilmiah, 1(1), 871-880. https://doi.org/10.23819/pi.v1i1.3580.

Abidah, A., Hidaayatullaah, H. N., Simamora, R. M., Fehabutar, D., \& Mutakinati, L. (2020). The Impact of Covid-19 to Indonesian Education and Its Relation to the Philosophy of "Merdeka Belajar." Studies in Philosophy of Science and Education, 1(1), 38-49. https://doi.org/10.46627/sipose.v1i1.9.

Agustin, M. (2020). Tipikal Kendala Guru PAUD dalam Mengajar pada Masa Pandemi Covid 19 dan Implikasinya. Jurnal Obsesi: Jurnal Pendidikan Anak Usia Dini, 5(1), 334-345. https://doi.org/10.31004/obsesi.v5i1.598.

Al-Fikry, I., Yusrizal, Y., \& Syukri, M. (2018). Pengaruh Model Problem Based Learning Terhadap Kemampuan Berpikir Kritis Peserta Didik Pada Materi Kalor. Jurnal Pendidikan Sains Indonesia, 6(1), 17-23. https://doi.org/10.24815/jpsi.v6i1.10776.

Aminah, S. (2021). Pengaruh Model Pembelajaran Problem Based Learning (PBL) Melalui Pembelajaran Online Terhadap Hasil Belajar Biologi Konsep Virus Pada Peserta Didik Kelas X Di SMA negeri 2 Enrekang. In Skripsi.

Assriyanto, K., Sukardjo, J., \& Saputro, S. (2014). Pengaruh Model Pembelajaran Berbasis Masalah Melalui Metode Eksperimen Dan Inkuiri Terbimbing Ditinjau Dari Kreativitas Siswa Pada Materi Larutan Penyangga di SMA N 2 Sukoharjo Tahun Ajaran 2013/2014. Jurnal Pendidikan Kimia Universitas Sebelas Maret, 3(3), 89-97. https://jurnal.fkip.uns.ac.id/index.php/kimia/article/view/4268.

Astika, I., Suma, M., \& Suastra, M. (2013). Pengaruh Model Pembelajaran Berbasis Masalah (Problem Based Learning) Terhadap Sikap Ilmiah Dan Ketrampilan Berpikir Kritis. Jurnal Pendidikan Dan $\begin{array}{llll}\text { Pembelajaran IPA Indonesia, } & 3(1) . & \text { https://ejournal- }\end{array}$ pasca.undiksha.ac.id/index.php/jurnal_ipa/article/view/851.

Aziz, A., Rokhmat, J., \& Kosim. (2015). Pengaruh Model Pembelajaran Berbasis Masalah Dengan Metode Eksperimen Terhadap Hasil Belajar Fisika Siswa Kelas X SMAN 1 Gunungsari Kabupaten Lombok Barat Tahun Pelajaran 2014/2015. Jurnal Pendidikan Fisika Dan Teknologi, 1(3), 200-204.

Basar, A. M. (2021). Problematika Pembelajaran Jarak Jauh Pada Masa Pandemi Covid-19. Edunesia : Jurnal Ilmiah Pendidikan, 2(1), 208-218. https://doi.org/10.51276/edu.v2i1.112.

Cahyo, R. N., Wasitohadi, W., \& Rahayu, T. S. (2018). Upaya Meningkatkan Hasil Belajar IPS melalui Model Problem Based Learning (PBL) Berbantuan Media Audio Visual pada Siswa Kelas 4 SD. Jurnal Basicedu, 2(1), 28-32. https://doi.org/10.31004/basicedu.v3i1.70. 
Farisi, A., Hamid, A., \& Melvina. (2017). Pengaruh Model Pembelajaran Problem Based Learning terhadap Kemampuan Berpikir Kritis dalam Meningkatkan Hasil Belajar Ssiswa pada Konsep Suhu dan Kalor. Jurnal Ilmiah Mahasiswa, 2(3), 283-287. http://www.jim.unsyiah.ac.id/pendidikanfisika/article/view/4979.

Febrina, D. A., \& Airlanda, G. S. (2020). Meta Analisis Pengaruh Problem Based Learning Terhadap Keterampilan Berpikir Kritis Di Sekolah Dasar. Jurnal Ilmiah Wahana Pendidikan, 6(4), 564-572. https://doi.org/10.5281/zenodo.4297499.

Ferazona, S., \& Suryanti, S. (2020). Pengaruh Pembelajaran Daring Terhadap Hasil Belajar Kognitif Mahasiswa Pada Mata Kuliah Limnologi. Journal of Research and Education Chemistry, 2(2), 102. https://doi.org/10.25299/jrec.2020.vol2(2).5826.

Handarini, O. I., \& Wulandari, S. S. (2020). Pembelajaran Daring Sebagai Upaya Study From Home (SFH). Jurnal Pendidikan Administrasi Perkantoran (JPAP), 8(3), 465-503. https://journal.unesa.ac.id/index.php/jpap/article/view/8503.

Harta, J. (2019). Analisis Keterampilan Metakognitif Mahasiswa dalam Mengkaji Implementasi Kurikulum Kimia di SMA melalui Project Based Learning. JRPK: Jurnal Riset Pendidikan Kimia, 9(2), 94-102. https://doi.org/10.21009/jrpk.092.06.

Hendriana, E. C. (2018). Pengaruh Model Pembelajaran Problem Based Learning Dan Gaya Belajar Auditorial Terhadap Hasil Belajar Ips Di Sekolah Dasar. Jurnal Pendiidikan Dasar Indonesia, 3(1), 1 - 8. https://doi.org/10.26737/jpdi.v3i1.484.

HS, E. F. H., Khaedar, M., \& Asriati. (2019). Peningkatan Hasil Belajar IPS Melalui Model Problem Based Learning (PBL) Pada Siswa Kelas IV SD Inpres Borong Jambu II Kota Makassar. Celebes Education Review, 1(1), 59-69. https://doi.org/10.37541/cer.v1i2.550.

Kiswanto, H., Sunarno, W., \& Suparmi, S. (2016). Pembelajaran Berbasis Masalah Menggunakan Metode Proyek Dan Eksperimen Ditinjau Dari Kreativitas Dan Kemampuan Berpikir Kritis Siswa. Inkuiri, 5(3), 57-65. https://jurnal.uns.ac.id/inkuiri/article/view/9444.

Kristiana, T. F., \& Radia, E. H. (2021). Meta Analisis Penerapan Model Problem Based Learning Dalam Meningkatkan Hasil Belajar IPA Siswa Sekolah Dasar. Jurnal Basicedu, 5(2), 818-826. https://doi.org/10.31004/basicedu.v5i2.828.

Kuswariningsih, S. (2016). Korelasi Kebiasaan Belajar, Kreatifitas Belajar dan Prestasi Belajar IPS. Jurnal Penelitian Dan Pendidikan IPS, 10(3), 389-395. http://ejournal.unikama.ac.id/index.php/JPPI.

Larumpa, Natalia, S, N., Korompis, C., \& Dehoop, S. (2020). Pengaruh Pembelajaran Berbasis Masalah dan Media Pembelajaran Berbasis Online Terhadap Hasil Belajar Siswa Pada Mata Pelajaran Pemasaran Online Kelas XI di SMK Negeri 2 TONDANO. LITERACY-Jurnal Pendidikan Ekonomi, 1(2), 37-53. http:// ejurnal-mapalus-unima.ac.id/index.php/jpe-unima/article/view/583.

Lidinillah, D. A. M. (2013). Pembelajaran berbasis masalah (problem based learning). Jurnal Pendidikan Inovatif, 5(1), 17.

Lidyawati, Gani, A., \& Khaldun, I. (2017). Penerapan Model Problem Based Learning Untuk Meningkatkan hasil Belajar Dan Keterampilan Berpikir Kritis Peserta Didik Pada Materi Larutan Penyangga. Jurnal Pendidikan Sains Indonesia (Indonesian Journal of Science Education), 5(1), 140-146. https://doi.org/10.24815/jpsi.v5i1.16552.

Marroquín, B., Vine, V., \& Morgan, R. (2020). Mental health during the COVID-19 pandemic: Effects of stayat-home policies, social distancing behavior, and social resources. Psychiatry Research, 293(July), 113419. https://doi.org/10.1016/j.psychres.2020.113419.

Nafis, Khusnul, A. (2020). Penerapan Model Pembelajaran Berbasis Masalah Dengan Metode Eksperimen Untuk Meningkatkan Hasil Belajar Dan Aktivitas Siswa Kelas VIII SMP 1 Mejobo Kudus Pada Mata Pelajaran IPA. In Skripsi.

Nisa, H. (2017). Pengaruh Pembelajaran Berbasis Masalah Terhadap Hasil Belajar Siswa Dan Sikap Siswa Pada Mata Pelajaran Kimia. In Skripsi.

Nurfitriyani, M. (2015). Pengaruh Kreativitas dan Kedisiplinan Mahasiswa Terhadap Hasil Belajar Kalkulus. Formatif: Jurnal Ilmiah Pendidikan MIPA, 4(3), 219-226. https://doi.org/10.30998/formatif.v4i3.157.

Nurkholis. (2020). Dampak Pandemi Novel-Corona Virus Disiase (Covid-19) Terhadap Psikologi Dan Pendidikan Serta Kebijakan Pemerintah. Jurnal PGSD, 6(1), 39-49. https://ejournal.umc.ac.id/index.php/JPS.

Ota, M. K., Djou, A. M. G., \& Numbah, F. F. (2021). Problematika Pembelajaran Daring Siswa Kelas Vii Smpn. Jurnal Pengabdian Masyarakat, 2(1), 74-81. https://doi.org/10.37478/mahajana.v2i1.769.

Patabang, A., \& Murniarti, E. (2021). Analisis Kompetensi Pedagogik Guru pada Pembelajaran Daring dimasa Pandemi Covid-19. Edukatif: Jurnal Ilmu Pendidikan, 3(4), 1418-1427. https://doi.org/10.31004/edukatif.v3i4.584. 
Pratiwi, Y., Redjeki, T., \& Masykuri, M. (2014). Pelaksanaan Model Pembelajaran Problem Based Learning (Pbl) Pada Materi Redoks Kelas X Sma Negeri 5 Surakarta Tahun Pelajaran 2013/2014. Jurnal Pendidikan Kimia Universitas Sebelas Maret, 3(3), 40-48. https://jurnal.fkip.uns.ac.id/index.php/kimia/article/view/4200.

Purwanto, A., Pramono, R., Asbari, M., Santoso, P. B., Wijayanti, L. M., Choi, C. H., \& Putri, R. S. (2020). Studi Eksploratif Dampak Pandemi COVID-19 Terhadap Proses Pembelajaran Online di Sekolah Dasar. EduPsyCouns: Journal of Education, Psychology and Counseling, 2(1), 1-12. https://ummaspul.ejournal.id/Edupsycouns/article/view/397.

Rahmawati, E. (2020). Penerapan Model Problem Based Learning Terhadap Hasil Belajar IPS Materi Pemanfaatan Sumber Daya Alam Pada Siswa Kelas IV Sekolah Dasar. Jurnal Primary (Kajian Ilmu Pendidikan Dasar Dan Humaniora), 1(1), 21-30. http://ejournal.stkippgrisidoarjo.ac.id/index.php/psd/article/view/51.

Rahmawati, I. Y., \& Yulianti, B. (2020). Kreativitas guru dalam proses pembelajaran ditinjau dari penggunaan metode pembelajaran jarak jauh di tengah wabah. AL-ASASIYYA: Journal Basic of Education, 5(1), 27-39. http://journal.umpo.ac.id/index.php/al-asasiyya/index.

Rosa, N. M., \& Pujiati, A. (2017). Pengaruh Model Pembelajaran Berbasis Masalah Terhadap Kemampuan Berpikir Kritis dan Kemampuan Berpikir Kreatif. Formatif: Jurnal Ilmiah Pendidikan MIPA, 6(3), 175-183. https://doi.org/10.30998/formatif.v6i3.990.

Sa, S., Mei, A., Mei, M. F., Sero, M. T., Seto, S. B., Naja, F. Y., Denny, K., Meke, P., \& Manda, G. S. (2021). Bimbingan Belajar di Rumah Menggunakan Alat Peraga Blok Pecahan Pada Masa Pandemi Covid19. Jurnal Pengabdian Masyarakat, 2(2), 193-201. https://doi.org/10.37478/mahajana.v2i2.1031.

Safithri, R., Syaiful, S., \& Huda, N. (2021). Pengaruh Penerapan Problem Based Learning (PBL) dan Project Based Learning (PjBL) Terhadap Kemampuan Pemecahan Masalah Berdasarkan Self Efficacy Siswa. Jurnal Cendekia: Jurnal Pendidikan Matematika, 5(1), 335-346. https://doi.org/10.31004/cendekia.v5i1.539.

Saputri, T. A. D. W. I., Madang, K., \& Santoso, L. M. (2021). Penerapan Model Problem Based Learning (PBL) Dalam Pembelajaran Secara Online Terhadap Aktivitas Dan Hasil Belajar Peserta Didik Pada MAateri Sistem Peredaran Darah Kelas XI SMA Negeri 2 Palembang. Sriwijaya University.

Saputro, O. A., \& Rayahu, T. S. (2020). Perbedaan Pengaruh Penerapan Model Pembelajaran Project Based Learning ( Pjbl) Dan Problem Based Learning ( Pbl ) Berbantuan Media Monopoli. Jurnal Imiah Pendidikan Dan Pembelajaran, 4(1), 185-193. https://doi.org/10.23887/jipp.v4i1.24719.

Suriana, Halim, A., \& Mursal. (2016). Penerapan Model Problem Based Learning (Pbl) Berbasis Eksperimen Untuk Meningkatkan Pemahaman Konsep USAha Dan Energi Ditinjau Dari Gaya Berpikir Siswa Di Man Rukoh Banda Aceh. Jurnal Pendidikan Sains Indonesia, 4(1), 123431. https://doi.org/10.24815/jpsi.v4i1.6591.

Syafari, Y., \& Montessori, M. (2020). Analisis Pembelajaran Daring Terhadap Motivasi Belajar Dan Prestasi Belajar Siswa Dimasa Pandemi Covid-19. Jurnal Basicedu, 5(3), 1295-1303. https://doi.org/10.31004/basicedu.v5i3.872.

Utama, K. H., \& Kristin, F. (2020). Meta-Analysis Pengaruh Model Pembelajaran Problem Based Learning (PBL) Terhadap Kemampuan Berpikir Kritis IPA Di Sekolah Dasar. Jurnal Basicedu, 4(4), 889-898. https://doi.org/10.31004/basicedu.v4i4.482.

Wijayanti, R. M., \& Fauziah, P. Y. (2020). Perspektif dan Peran Orangtua dalam Program PJJ Masa Pandemi Covid-19 di PAUD. Jurnal Obsesi: Jurnal Pendidikan Anak Usia Dini, 5(2), 1304-1312. https://doi.org/10.31004/obsesi.v5i2.768.

Wulandari, A., dan Rohaeti, E. (2017). "Pengaruh Penerapan Metode Eksperimen Berbasis Problem Based Learning terhadap Sikap Ilmiah dan Prestasi Belajar Kimia." Pengaruh Penerapan Metode, 6(1), 19.

Yunitasari, R., \& Hanifah, U. (2020). Pengaruh Pembelajaran Daring terhadap Minat Belajar Siswa pada Masa COVID 19. Edukatif: Jurnal Ilmu Pendidikan, 2(3), 232-243. https://doi.org/10.31004/edukatif.v2i3.142.

Zakia, A. R., Djamahar, R., \& Rusdi, R. (2019). Pengaruh Pembelajaran Berbasis Masalah Menggunakan Media Sosial E-Learning Terhadap Hasil Belajar Siswa Sekolah Menengah Pada Sistem Pencernaan. JPBIO Jurnal Pendidikan Biologi), 4(1), 21-28. https://doi.org/10.31932/jpbio.v4i1.395. 